\title{
Breast Leiomyosarcoma
}

National Cancer Institute

\section{Source}

National Cancer Institute. Breast Leiomyosarcoma. NCI Thesaurus. Code C5186.

An aggressive malignant smooth muscle neoplasm, arising from the breast. It is characterized by a proliferation of neoplastic spindle cells. 